\title{
EARLY CORRECTION OF SEVERE UNILATERAL INFANT PTOSIS WITH THE MERSILENE MESH SLING
}

\author{
DENNIS S. C. LAM, SONAL R. GANDHI, JOAN S. K. NG, IVAN N. CHEN, \\ PETER S. K. KWOK AND GUY H. CHAN \\ Shatin, Hong Kong
}

\begin{abstract}
SUMMARY
Ten consecutive cases of severe unilateral congenital ptosis were surgically corrected before 1 year of age (range 3-11 months) in an attempt to achieve early functional and cosmetic improvement. In all cases, a frontalis suspension using Mersilene mesh was performed. With a mean follow-up of $\mathbf{4 0 . 3}$ months (range 33-54 months), all patients achieved normal or near normal eyelid position and all had their chin-up head posture resolved. One patient developed a mild exposure keratitis that was treated successfully with topical antibiotics and lubricants. Our findings suggest that the Mersilene mesh sling has good potential for ptosis management in infants who are too young for fascial harvesting. However, a larger series with a longer follow-up period is required before the eventual safety and efficacy of the Mersilene mesh sling can be properly ascertained.
\end{abstract}

The optimal time to correct severe unilateral congenital ptosis has yet to be defined. It has been hypothesised that for children under 1 year of age, early surgical repair of severe congenital ptosis could alleviate associated functional, developmental and cosmetic problems. ${ }^{1}$ Associated bizarre head postures are frequently present in infancy that may contribute to problems of sitting and walking, and difficulty in achieving other developmental milestones. $^{2}$

There is a $14-20 \%$ incidence of amblyopia in patients with ptosis, of which $2.3-4 \%$ is directly

From: Department of Ophthalmology \& Visual Sciences, Prince of Wales Hospital, The Chinese University of Hong Kong.

Correspondence to: Dr Dennis S. C. Lam, Department of Ophthalmology \& Visual Sciences, Prince of Wales Hospital, The Chinese University of Hong Kong, Shatin, N.T., Hong Kong. Tel: (852) 2632 2881. Fax: (852) 26483589. attributable to stimulus deprivation. ${ }^{3-5}$ The period of reversibility, or critical period, for deprivation amblyopia remains to be determined. For unilateral congenital cataract, however, there is evidence suggesting that surgical and refractive correction must be done within the first 4 months of life if good visual outcome is to be obtained. ${ }^{6}$ Nevertheless, this may not apply to ptosis, especially when the child makes an attempt to use both eyes together by head posturing.

A major problem for the correction of ptosis in infants is the lack of an ideal sling material. Different types of material for brow suspension have been advocated, but the use of autogenous fascia lata remains the most popular and the most effective. ${ }^{7-10}$ However, this is not possible in children under 3 years of age because fascia lata has not yet developed sufficiently. ${ }^{11}$ Stored, irradiated and lyophilised fascia has been used, but the results are less satisfactory and fascial banks are necessary for storage. ${ }^{12}$ Other synthetic materials such as Supramid, Prolene and silicone give only temporary results and are not good for permanent use.$^{8,13-15}$ Mersilene mesh (MM) is a synthetic non-absorbable macromesh and is biocompatible. It has been used successfully in a variety of clinical settings including general, vascular and orthopaedic surgeries. The mesh has been shown to be able to act as a permanent scaffold supporting fibrovascular ingrowth. ${ }^{16}$ Initial results using MM for sling surgery have been encouraging. ${ }^{17-19}$ We report herein a prospective study of a series of 10 consecutive infants who underwent corrective ptosis surgery prior to 1 year of age. To our knowledge, this is the first reported series in the literature using $\mathrm{MM}$ for correcting severe unilateral congenital ptosis in infants. 


\section{MATERIALS AND METHODS \\ Subjects}

Patients were recruited from the Eye Unit of the Prince of Wales Hospital from March 1992. All patients were less than 1 year of age (range 3-11 months) at the time of surgery. They were otherwise healthy. A pre-operative complete eye examination including full face photography was performed for all patients. All had a normal blink reflex and good Bell's phenomenon. The degree of ptosis was assessed by estimating the difference between the palpebral apertures in primary gaze. All patients had poor levator function (less than $5 \mathrm{~mm}$ ) on the affected side. Informed consent was obtained from the parents of all patients.

\section{Sling Materials}

We prepared the sling in a manner similar to that described by Downes and Collin. ${ }^{17}$ The sling was cut from a sheet of MM (supplied by Ethicon) to the dimensions of $15 \mathrm{~cm}$ long by $7 \mathrm{~mm}$ wide. The MM strips were then autoclaved, packed and stored for later use.

\section{Surgical Techniques}

The surgical technique employed was a double trapezoid procedure as described by Iliff. ${ }^{20}$ After the ends of the two MM strips had been passed through the brow incision over the temporal side, they were pulled tight until the lid rested just above the superior limbus. They were then tied with two 5.0 Ethibond sutures passed through the MM just within the brow incision. The ends on the nasal side were tightened and tied in a similar fashion. The excess MM was trimmed and the sling allowed to retract back into the deep brow space. Pulling from the lid margin with a blunt-toothed forceps helped to ensure adequate retraction of the MM into the deep brow tissue and reduced the chance of delayed mesh extrusion. The brow incisions were closed with a 6-0 silk suture and a Frost suture was then applied. Broad spectrum oral antibiotics were prescribed for 1 week. Topical antibiotics and lubricants were routinely used for the first 2 weeks and subsequently as required.

\section{RESULTS}

Ten consecutive patients, each with severe unilateral congenital ptosis (Fig. 1) occluding part or all of the visual axis and with a prominent chin-up posture, underwent frontalis suspension using the MM sling. Surgical outcome was judged as either good, moderate or poor, based on the criteria described by Manners: ${ }^{13}$

1. Good: the post-operative lid position was maintained within $1 \mathrm{~mm}$ of the superior limbus.

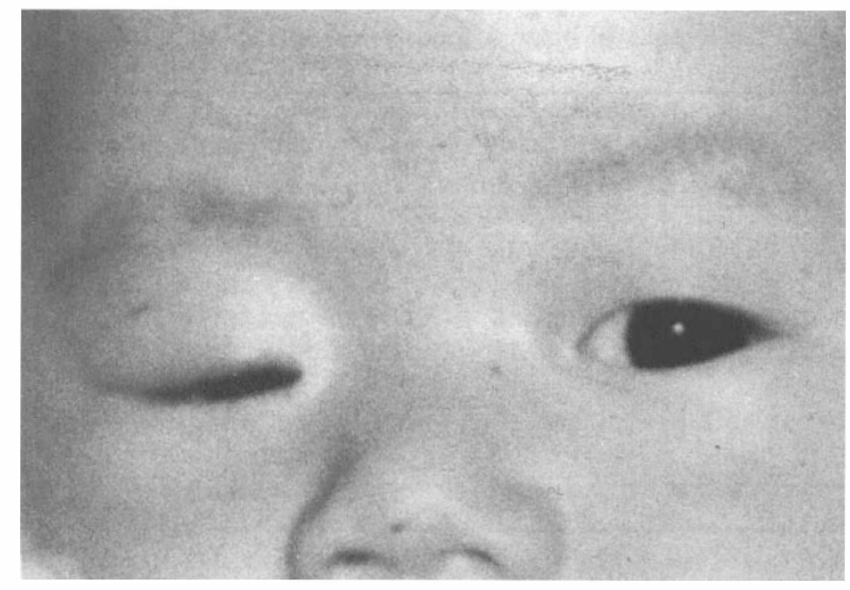

Fig. 1. Case 1. Right congenital ptosis pre-operatively.

2. Moderate: the post-operative lid position dropped more than $1 \mathrm{~mm}$ below the superior limbus but remained clear of the visual axis.

3. Poor: the post-operative lid position dropped to obscure the visual axis.

The results of the 10 patients are shown in Table I. All patients maintained a lid position clear of the visual axis (Fig. 2). With a mean follow-up of 40.3 months (range 33-54 months), all except one had good results with the lid position maintained within $1 \mathrm{~mm}$ of the superior limbus. All patients had a smooth lid contour. Three patients had clinically insignificant lagophthalmos at the latest follow-up whereas the other 7 had complete lid closure.

Patient 7 developed mild recurrence of ptosis at about 3 months after surgery, but the visual axis remained clear. There were no instances of wound infection, stitch granuloma, fistula or extrusion of the sling in the follow-up period. Patient 5 developed mild exposure keratitis 3 weeks after the operation. This was treated successfully with topical antibiotics and lubricants with no consequence.

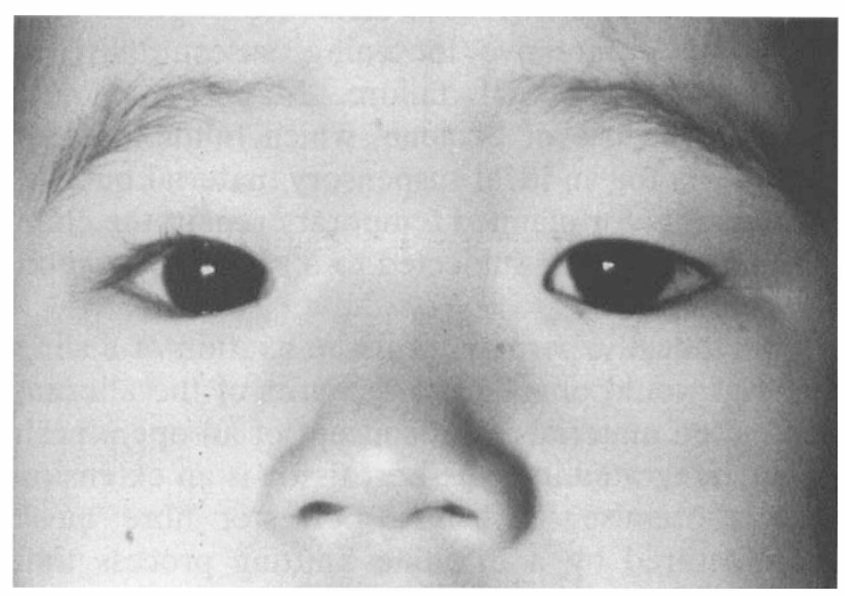

Fig. 2. Case 1. Post-operative appearance. 
Table I. Results of brow suspensions with the Mersilene mesh sling

\begin{tabular}{|c|c|c|c|c|c|}
\hline Patient no. & Side & $\begin{array}{c}\text { Age at } \\
\text { surgery } \\
\text { (months) }\end{array}$ & $\begin{array}{l}\text { Ptosis } \\
(\mathrm{mm})\end{array}$ & $\begin{array}{c}\text { Follow-up } \\
\text { time } \\
\text { (months }\end{array}$ & Result \\
\hline 1 & Right & 7 & 6 & 54 & Good \\
\hline 2 & Left & 4 & 6 & 44 & Good \\
\hline 3 & Right & 3 & 5 & 44 & Good \\
\hline 4 & Right & 6 & 4 & 42 & Good \\
\hline 5 & Right & 11 & 4 & 42 & Good \\
\hline 6 & Left & 11 & 4 & 37 & Good \\
\hline 7 & Left & 6 & 5 & 36 & Moderate \\
\hline 8 & Left & 9 & 5 & 36 & Good \\
\hline 9 & Left & 6 & 4 & 35 & Good \\
\hline 10 & Left & 6 & 5 & 33 & Good \\
\hline
\end{tabular}

\section{DISCUSSION}

Although frontalis suspension is a useful method for raising the upper eyelid in severe ptosis with minimal levator function, we are still in search of the ideal sling material. Autogenous fascia lata has been used most frequently, mainly for its long-lasting effect, but it has its own problems. There is also a certain reluctance to use it on the part of ophthalmic surgeons because it involves a separate operation in an area unfamiliar to them. General anaesthesia is invariably required and controversy exists on the best means of obtaining such tissue to minimise complications. These factors, along with the lack of availability of suitable tissue in children under the age of 3 years, are major drawbacks.

Wilson $e t$ al. $^{21}$ investigated the permanence of banked lyophilised human fascia lata in a study with a mean post-operative follow-up of 7.2 years and found increasing numbers of failures with increasing length of follow-up, the success rate from surgery falling from $90 \%$ at $2-3$ years to $50 \%$ at $8-9$ years. In addition, many parents feel that the use of donor material in their children is unacceptable because of the potential risk of cross-infection.

The most widely used synthetic material is a polyfilament cable-type suture, which has the advantages of ease in handling and commercial availability but does have an increased incidence of granuloma formation, progressive loosening, susceptibility to trauma and eventual failure. Manners et al. ${ }^{13}$ reported the use of Prolene, which fulfils most of the criteria for an ideal suspensory material but can be used only for planned temporary repair; the child therefore has to be subjected to a second operation later in life.

Theoretically, permanent tissue fixation of a sling material would obviate the demerits of the alternatively used materials. The concept of an open mesh that is integrated into the host tissue is an extension of this premise. MM is a polyester fibre mesh manufactured by a machine knitting process that interlocks individual fibre junctions. This feature prevents unravelling and facilitates cutting of the mesh without disruption of adjacent fibre junctions. ${ }^{22}$ Downes and Collin $^{16}$ reported a case in which evidence of permanent tissue incorporation was seen at the time of re-operation on the patient. A portion of the excised mesh showed ingrowth of fibrovascular tissue within the mesh structure. The subsequent incorporation of the mesh into the host tissue, apart from providing a theoretical basis for a possible long-lasting suspensory effect, may also account for the good lid movement and closure.

It is well recognised that occlusion of the visual axis by a ptotic upper eyelid in infancy and early childhood may lead to sensory deprivation amblyopia with or without strabismus. ${ }^{4,5}$ Ptosis also markedly influences vision, after maturation of the visual pathways, if severe enough to occlude the visual axis partially or totally. In each of the situations, early ptosis surgery is indicated and preferred.

Mersilene mesh is our preferred suspension material for infants as it is inexpensive, readily available, and easily prepared and handled. We have found that brow suspension with Mersilene mesh can be easily performed even in infants under 1 year of age.

Our medium-term results obtained with the Mersilene sling suggest that it may be a good alternative to other materials available for use in brow suspension ptosis surgery for infants. However, we are still awaiting results regarding its long-term effect on a larger number of patients to ascertain accurately the eventual long-term success and complication rates.

The authors would like to thank Professor Mark O.M. Tso and $\mathrm{Mr}$ Christopher Liu for their helpful comments and contribution to the preparation of this manuscript.

Key words: Brow suspension, Infant, Ptosis, Mersilene mesh.

\section{REFERENCES}

1. Saunders RA, Grice CM. Early correction of severe congenital ptosis. J Pediatr Ophthalmol Strabismus 1991;28:271-3.

2. Tanenbaum M. Childhood ptosis: diagnosis and treatment. Int Paediatr 1990;5:244-8.

3. Anderson RL, Baumgartner SA. Amblyopia in ptosis. Arch Ophthalmol 1980;98:1068-70.

4. Harrad RA, Graham CM, Collin JRO. Amblyopia and strabismus in congenital ptosis. Eye 1988;2:625-7.

5. Stark N, Walther C. Refraktionsfehler, Amblyopie und Schieldeviationen bei kongenitaler ptosis. Klin Monatsbl Augenheilkd 1984;184:37-9.

6. Robb RM, Mayer DL, Moore BD. Results of early treatment of unilateral congenital cataracts. J Pediatr Ophthalmol Strabismus 1987;24:178-81.

7. Lam DSC, Lam TP, Chen IN, Tsang GH, Gandhi SR. Palmaris longus tendon as a new autogenous material for frontalis suspension surgery in adults. Eye 1996;10:38-42.

8. Carter SR, Meecham WJ, Seiff SR. Silicon frontalis slings for the correction of blepharoptosis. Ophthalmology 1996;103:623-30. 
9. Kemp EG, James CR, Collin JRO. Brow suspension in the management of ptosis: an analysis of over 100 cases. Trans Ophthalmol Soc UK 1986;105:84-7.

10. Crawford JS. Repair of ptosis using frontalis and fascia lata: a 20 year review. Ophthalmic Surg 77;8:31-40.

11. Crawford JS. Recent trends in ptosis surgery. Ann Ophthalmol 1975;7:1263-7.

12. Broughton WL, Matthews II JG, Harris DJ Jr. Congenital ptosis: results of treatment using lyophilised fascia lata for frontalis suspensions. Ophthalmology 1982;89:1261-6.

13. Manners RM, Tyers AG, Morris RJ. The use of Prolene as a temporary suspensory material for brow suspension in young children. Eye 1994;8:346-8.

14. Katowitz JA. Frontalis suspension in congenital ptosis using a polyfilament cable type suture. Arch Ophthalmol 1979;97:1659-63.

15. Wagner RS, et al. Treatment of congenital ptosis with frontalis suspension. Ophthalmology 1984;91:245-8.
16. Downes RN, Collin JRO. The Mersilene mesh ptosis sling. Eye 1990;4:456-63.

17. Downes RN, Collin JRO. The Mersilene mesh sling: a new concept in ptosis surgery. $\mathrm{Br} \mathrm{J}$ Ophthalmol 1989;73:498-501.

18. Hintschich CR, et al. Mersilene mesh brow suspension: efficiency and complications. Br J Ophthalmol 1995;79: 358-61.

19. Elder MJ. Mersilene mesh and fascia lata in brow suspension: a comparative study. Ophthalmic Surg 1993;24:105-8.

20. Iliff NT. Surgery of the eyelids and lacrimal drainage apparatus. In: Rice TA, Michaels RG, Stark WJ, editors. Operative surgery - ophthalmic surgery. 4th ed. London: Butterworth, 1988:35-7.

21. Wilson ME, Johnson RW. Congenital ptosis: long term results of treatment using lyophilised fascia lata for frontalis suspension. Ophthalmology 1991;98:1234-7.

22. Product sheet: Mersilene mesh. Revised September 1985, Ethicon Ltd. 